\title{
Assessing The Impact Path of Air Quality On Enterprise R\&D Investment: Empirical Evidences From Dual Perspectives of Investor Sentiment And Government Concern
}

\author{
Jialiang Yang \\ Jiangsu University \\ Dan He ( $\nabla$ hedan@ujs.edu.cn ) \\ Jiangsu University
}

\section{Research Article}

Keywords: Investment, Financial Enterprises, Air quality, Enterprise R\&D investment, Investor sentiment

Posted Date: December 1st, 2021

DOI: https://doi.org/10.21203/rs.3.rs-1093671/v1

License: (c) (1) This work is licensed under a Creative Commons Attribution 4.0 International License. Read Full License 


\section{Abstract}

Based on the data of Shanghai and Shenzhen A-share listed companies from 2015 to 2019, this paper studies the influence paths of air quality on R\&D investment of listed companies from the perspectives of investor sentiment and government concern. It is found that, on the whole, air quality has a significant inhibitory effect on R\&D investment. Air quality has a significant promoting effect on investor sentiment, which serves as a path to further restrain the R\&D investment of listed companies. Air pollution is an effective concern for the government, and serves as a veil between air quality and R\&D investment. Furthermore, this paper analyzes the heterogeneity of enterprises from the aspects of regional technology complexity, property right nature, whether it is a polluting enterprise or not, and whether it is a key regulated enterprise or not, and comes to relevant conclusions. This paper expands the research on air quality and enterprise R\&D investment decision-making, which helps to clarify and improve the transmission mechanism and implementation effect of environmental protection policies.

\section{Introduction}

"China Ecological Environment Bulletin 2019" shows that in 2019, China's urban air quality standards accounted for 46.6 percent of the total number of cities, an increase of $10.8 \%$ compared to 2018 , and the number of city ambient air quality exceeding the standard was 180 , accounting for $53.4 \%$ of the total number of cities. A total of 452 days of serious pollution occurred in 337 cities, 183 days less than in 2018; 1,666 days of serious pollution, 88 days more than in 2018 . For a long time, the rapid growth of China's economy based on energy consumption has caused serious imbalance of China's ecological environment, especially the air quality problem. The economic high-efficiency growth pattern with independent innovation as the core is the core path to realize the high-quality development of China's economy (He et al. 2020), and a significant leap in scientific and technological strength is set as one of the long-term goals in the 14th Five-Year Plan.

China's economy has been in a period of continuous development in recent decades, while high-frequency economic activities have led to a continuous decline in air conditions. The search for the high-quality development of both air and economy has been the focus of many scholars' research. The available literature on air pollution has focused on environmental pollution and social welfare (Wang et al. 2021), the formation of air pollution (Vega et al. 2021), governance mechanism and effect (Liu et al. 2021), labor supply, and resident's happiness (Li et al. 2020; Sanduijav et al. 2021) and other macro and meso-level studies. However, there are few researches on the impact of air pollution on micro- enterprises' R\&D and innovation behavior, and the impact paths are mainly focused on the perspectives of regulatory mechanisms (Wang et al, 2021; Zhang et al, 2020), human capital (Liu et al. 2021), and corporate social responsibility (Wang et al. 2021) and so on. On the basis of previous studies, this paper takes investor sentiment and government concern as the core paths to explore the effect of air pollution on enterprise R\&D investment. The domestic and foreign references for the two are summarized as follows.

In the aspect of air pollution and investor sentiment, from the point of view of environmental psychology, the negative effect of air pollution has been concluded, and the negative effect of air pollution is the result 
of the interaction of many factors. Psychologists have long known that environmental factors influence people's moods, thoughts, and judgment (Hirshleifer and Shumway 2003; Jacobsen and Marquering, 2008). The psychological effects of air pollution were not only associated with life satisfaction and subjective well-being (Dolan and Laffan, 2016), but also correlated with people's mood (Lim et al. 2012). Among the possible adverse effects of air pollution, emotional reactions may be the most sensitive (Power et al, 2015). Weather factors can directly affect individual behavior and individual psychological processes, or have an indirect effect on individual behavior. In addition, weather factors will have a direct impact on various activities within the enterprise and the enterprise relations in the industrial chain or have an indirect impact on the business behavior (Gao and Zhang, 2020). There is a negative relation between air pollution and an enterprise's stock return, and the air pollution effect is particularly strong for enterprises that are more likely to be held by local investors, such as younger enterprises, enterprises with lower institutional ownership, and enterprises covered by fewer analysts(Ding et al. 2021). Severe air pollution results in low returns, turnover, volatility, and high illiquidity. The relationship between air pollution and the local enterprise performance is not significant, implying that the air pollution effects can be attributed to the emotional bias of investors (Wu et al. 2018).

The innovation of knowledge has the characteristics of large demand of fund support, high risk of innovation activities, and obvious uncertainly of benefits. Therefore, the R\&D investment of enterprises has become the leading factor to realize innovation activities (Song et al. 2021). In terms of investor sentiment and enterprise R\&D, pessimistic individual investor sentiment reduces liquidity and volatility, and the mispricing caused by the individual investor sentiment cannot be eliminated by using risk-factor models (Wu and Lu, 2020). Market sentiment further affects R\&D investments by influencing manager sentiment (Dang and Xu. 2018). High or low market sentiment reflects investors' general optimism or pessimism about asset prices (Brown and Cliff, 2005), and this kind of irrational sentiment will lead to mispricing of the stock and have an important influence on the capital investment decision of the enterprise (Baker and Wurgler. 2004; Polk and Sapienza. 2009). Besides, high or low investor sentiment can "shape" managers' homogeneous sentiment and thus influence the enterprise's investment and other decision-making behavior (Nofsinger, 2005). Based on the above facts, the adverse effects of air pollution will affect both the investment behavior of micro-individuals and the innovation activities of enterprises. Therefore, this paper tries to analyze how air quality affects enterprise R\&D investment by taking individual investor behavior, namely investor sentiment, as an influence path.

In addition, as the main body of micro-development, enterprises are the focus of the government's attention, and also the foothold of implementing relevant environmental regulation policies. The implementation effect of the relevant government policies will be reflected through the overall effect of all micro-enterprises' individual innovation behavior. In air quality and government supervision, China's coal-based, energyintensive development path has led to severe air pollution problems (Du et al. 2018; Hein et al. 2019). And air pollution is a major threat to human health and life satisfaction ( Han et al. 2017; Tang et al. 2018). Severe air pollution associated with rapid urbanization is a pressing issue in China. The Chinese public's awareness of environmental protection is awakening, which poses enormous pressure on governments to enforce environmental regulations (Lu et al. 2018). The Chinese government has proposed to establish an 
ecological compensation (EC) mechanism for air quality to deal with the country's serious air pollution problem (Cui et al. 2021). In government supervision and enterprise R\&D investment, the Chinese government R\&D subsidies have a significant incentive effect on enterprise technology innovation investment (Jia et al. 2021). And government public support is an important policy tool to support enterprises in carrying out innovation and R\&D in China (Xiang et al. 2021). But there are different conclusions. Although government support can help alleviate financial constraints and encourage funded enterprises to invest in innovative activities (Buisseret et al. 1995), such support may simply induce funded enterprises to replace their R\&D investment with scarce public funds, thereby crowding out their spending (Zúñiga-Vicente et al. 2014).

Therefore, this paper tries to analyze the relationship between air governance and corporate R\&D investment by using government supervision as another influence path. Government supervision plays an important role in regulating the market, building investor confidence, and relieving the financing difficulties of R\&D enterprises. Therefore, based on the reality of China's capital market and the reality of listed companies, the government supervision factor is embedded into the research category of air pollution and enterprise R\&D investment, and it is necessary to further reveal how the institutional factors affect and intervene the process of air pollution's effect on enterprise micro-R\&D investment. On the one hand, under the pressure of environmental performance assessment and social and media attention, regional air pollution will force the government to pay more attention to, formulate and revise relevant environmental protection policies. Various positive fiscal and taxation policies formulated by the government can encourage technological innovation of enterprises, regulate the market by means of "visible hands", maintain and boost investor confidence, and enhance the influence of the capital market on enterprise innovation, and drive the transformation and adjustment of the innovation economy. The impact mechanism of this paper is shown in Fig. 1. In a word, enterprise R\&D level is the key field of green and lowcarbon industry transformation in China. It is the key to carry out the strategy of innovation-driven development in the context of high-quality economic development to probe into the path and main obstacles of R\&D from the micro-perspective of enterprises.

\section{Data And Methodology}

\subsection{Sample and data sources}

This paper selected all the listed companies of Shanghai and Shenzhen A-shares as the sample of enterprises, in which the enterprises with missing data were excluded. Furthermore, the daily Air Quality Index (AQI) of prefecture-level cities across the country was collected from the Ministry of Ecology and Environment of the People's Republic of China. Considering the great changes of air quality evaluation index system in China after 2014, this paper only selected air quality data in 2015 and later, in order to ensure the consistency of calculation of air pollution degree. This paper selected the sample of enterprises from 2015 to 2019, and processed the sample according to the following principles: (1) Eliminating companies with incomplete data; (2) Considering the significance of extreme weather in the study of this paper,, this paper only conducted Winsorize (1\%) treatment on the continuous variables of financial 
indicators. The data in this paper are mainly from the CSMAR database, and the data of macro-economic level are from the Statistical Yearbook of Chinese Cities. In the city's technical complexity data, the patent data comes from the State Intellectual Property Office.

\subsection{Econometric model and variable selection}

In order to analyze the impact path of air pollution on R\&D investment of enterprises, this paper sets up an extensible benchmark measurement model (1) as follows. To avoid spurious regression, this paper will take the logarithm treatment with the explanatory variables:

$$
\ln C R D_{i t}=\beta_{0}+\beta_{1} A Q I_{i j t}+\beta_{2} X_{i t}+D u m m y+\varepsilon_{i t}
$$

1

Where $\beta_{0}$ is a constant term, $\beta_{1}$ and $\beta$ - represent regression coefficients, i represents the listed company, $t$ represents the year, j represents the prefecture-level city where the listed company $i$ is located, $C_{\text {it }}$ represents the $R \& D$ investment of enterprise $i$ in the $t$ period, $A Q I_{i j t}$ represents the degree of air pollution in period $t$ of $j$ where enterprise $i$ is located, $X_{i}$ represents the control variable at the enterprise level and the macro level, Dummy represents the corresponding Virtual variable, and $\varepsilon_{\text {it }}$ represents the error term.

Based on the above analysis of the impact mechanism of air quality on R\&D investment of enterprises, this paper studies and discusses the possible impact path through the intermediary effect model. By referring to the step-by-step method of testing the intermediate effect proposed by Baron and Kenny (1986), the following mediating effect model for testing is constructed (Baron and Kenny, 1986):

$$
\begin{gathered}
y_{i t}=a_{0}+a_{1} x_{i t}+a_{j} \text { control }_{i t}+\text { Dummy }+\varepsilon_{i t} \\
m_{i t}=b_{0}+b_{1} x_{i t}+b_{j} \text { control }_{i t}+\text { Dummy }+\varepsilon_{i t} \\
y_{i t}=c_{0}+c_{1} x_{i t}+c_{2} m_{i t}+c_{j} \text { control }_{i t}+\text { Dummy }+\varepsilon_{i t}
\end{gathered}
$$

2

Where $y_{i t}$ is the explained variable, $x_{i t}$ is the explanatory variable, and $m_{i t}$ represents the intermediate variable, including investor sentiment (Sent) and government supervision (GS).

When the coefficient $a_{1}$ is significant, if the coefficient $b_{1}$ and $c_{2}$ are significant, it indicates that there is an indirect effect. At this time, when $c_{1}$ is not significant, there is a complete intermediate effect. When $c_{1}$ is significant, if $b_{1}{ }^{*} c_{2}$ and $c_{1}$ have the same sign, there is a partial intermediate effect; if $b_{1}{ }^{*} c_{2}$ and $c_{1}$ have different signs, there is a masking effect. The related variables and their symbols and definitions involved in this paper are shown in Table 1. 
Table 1

Symbols and definitions of variables

\begin{tabular}{|c|c|c|}
\hline Variable & $\begin{array}{l}\text { Variable } \\
\text { symbol }\end{array}$ & Definition \\
\hline $\begin{array}{l}\text { Listed company's } \\
\text { R\&D investment }\end{array}$ & CRD & $\begin{array}{l}\text { Annual R\&D expenditure / Main business income of listed } \\
\text { companies }\end{array}$ \\
\hline $\begin{array}{l}\text { Listed companies' } \\
\text { R\&D personnel }\end{array}$ & CRP & Listed companies \\
\hline Air quality & AQI & $\begin{array}{l}\text { The average daily air quality index of the city where the listed } \\
\text { companies are located }\end{array}$ \\
\hline Investor sentiment & Sent & $\begin{array}{l}\text { The semi-annual momentum index, namely the cumulative monthly } \\
\text { stock returns from July to December of the previous year }\end{array}$ \\
\hline $\begin{array}{l}\text { Government } \\
\text { supervision }\end{array}$ & GS & Total annual government subsidies for listed companies \\
\hline Asset-liability ratio & ALE & $\begin{array}{l}\text { Total liabilities at the end of period / Total assets at the end of } \\
\text { period }\end{array}$ \\
\hline Enterprise size & Size & Natural logarithm of total assets at the end of period \\
\hline Cash stock & Cash & $\begin{array}{l}\text { The sum of monetary funds and short-term investments at the end } \\
\text { of period / Total assets }\end{array}$ \\
\hline Free cash flow & FCF & Operating cash flow/Total assets at the end of period \\
\hline $\begin{array}{l}\text { Technical } \\
\text { complexity }\end{array}$ & TCD & $\begin{array}{l}\text { Screen and compare technological innovation systems in different } \\
\text { regions to reflect regional technological competitive advantages }\end{array}$ \\
\hline $\begin{array}{l}\text { City year-end } \\
\text { population }\end{array}$ & CYP & Year-end population of the city where the listed company is located \\
\hline GDP growth rate & GDP & GDP growth rate of the city where the listed company is located \\
\hline $\begin{array}{l}\text { Virtual variables of } \\
\text { key pollution control }\end{array}$ & Control & Key pollution monitoring enterprises are 1 and the rest are 0 \\
\hline $\begin{array}{l}\text { Virtual variables of } \\
\text { state-owned } \\
\text { enterprise }\end{array}$ & State & State-owned enterprises are 1 and the rest are 0 \\
\hline $\begin{array}{l}\text { Virtual variables of } \\
\text { polluting enterprise }\end{array}$ & Pollute & Polluting enterprises are 1 and the rest are 0 \\
\hline
\end{tabular}

\section{(1) Explained variable - enterprise R\&D investment (CRD)}

Referring to related research, this paper uses R\&D expenditure / main business income as a substitute variable for innovation input (Hansen and Hill, 1991). At the same time, R\&D personnel investment is another commonly used measurement indicator for the investment in R\&D and innovation of enterprises. 
Therefore, this paper adopts R\&D personnel investment as another substitute variable of enterprise $R \& D$ investment to ensure the robustness of the empirical results.

\section{(2) Core explanatory variable-air quality (AQI)}

This paper uses the average daily air quality index of the city where the enterprise is located to measure air pollution, namely the average air quality index.

\section{(3) Intermediate variable-investor sentiment (Sent) and government supervision (GS)}

Investor sentiment (Sent): In this paper, we consider the time-effect of momentum effect, which is usually 312 months. However, the momentum index of China's stock market is significant in the half-year period, and beyond the half-year period or longer will be reversed. Therefore, this paper uses half-year momentum index as the substitute variable of investor sentiment to carry on the follow-up study. That is, the cumulative monthly rate of return Sent which considers cash bonus with a six-month lag period, is used to measure

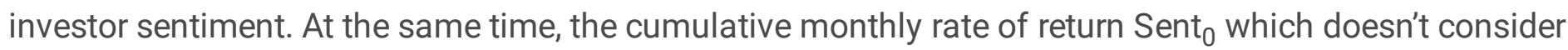
cash bonus with a six-month lag period, is used test the robustness.

Government supervision (GS): It is common practice at home and abroad that R\&D funds are funded by the government and social forces are involved. How the government encourages and promotes more social forces to participate in R\&D investment is an issue that needs to be paid attention to in China's current science and technology innovation. For micro-level enterprises, this paper uses the calculation of R\&D concern of regional governments for reference, and uses the total of government subsidies to enterprises (total of government subsidy profits, VAT returns, subsidies, etc.) to represent the government supervision.

\section{(4) Control variable}

According to the research of related scholars, this paper selects asset-liability ratio (ALE), enterprise size (Size), cash stock (Cash), free cash flow (FCF), technical complexity (TCD), city year-end population (CYP), and GDP growth rate (GDP) as control variables. The regional technical complexity can be divided into large technical complexity $(T C D)$ and small technical complexity $\left(T C D_{0}\right)$ according to the types of patent classification.

\section{(5) Virtual variable}

In this paper, the heterogeneity of the research questions is analyzed by Virtual variables, which are based on whether the listed enterprise is a key pollution monitoring enterprise (key pollution monitoring enterprises are 1 and the rest are 0), whether it is a state-owned enterprise (state-owned enterprises are 1 and the rest are 0 ), whether it is a polluting enterprise (polluting enterprises are 1 and the rest are 0 ), whether the location of listed companies is a high-tech complexity area (high-tech complexity areas are 1 and the rest are 0 ), etc.

\section{Empirical Results And Analysis}




\section{Descriptive statistics}

Table 2 shows the descriptive statistical results of the main variables. The mean value of listed companies' R\&D investment (CRD) is 4.111 and the standard deviation is 1.451 , indicating that there is a large gap in the R\&D investment status among different listed companies. The mean value of air quality (AQI) is 2.983 , the median is 2.994 and the standard deviation is 0.708 , indicating that the air quality in cities of China has been evenly distributed in recent years and in some areas it has been improved. The mean value of investor sentiment is -0.007 and the standard deviation is 0.342 , the maximum stock return is 13.197 and the minimum is -0.044 , indicating that the impact of investor sentiment on the returns of various enterprises is very different. The mean value of government supervision is 51.068 and the standard deviation is 246.852 , indicating that the government's support is obvious but there is great heterogeneity. The statistical results of other variables are in line with overall situation of enterprises in China. Therefore, it is very necessary to analyze the heterogeneity of the research in this paper. From the statistical results, we can see that non-key pollution monitoring companies, non-state-owned companies, non-pollution companies accounted for a large proportion of the sample. 
Table 2

Descriptive statistical analysis of variables

\begin{tabular}{|lllllll|}
\hline Variable & N & $\begin{array}{l}\text { Mean } \\
\text { value }\end{array}$ & $\begin{array}{l}\text { Standard } \\
\text { deviation }\end{array}$ & Minimum & Median & Maximum \\
\hline $\begin{array}{l}\text { Continuous } \\
\text { variable }\end{array}$ & & & & & & \\
\hline InCRD & 11787 & 4.111 & 1.451 & -8.722 & 4.071 & 9.993 \\
\hline AQI & 11787 & 2.983 & 0.708 & 0.003 & 2.994 & 5.378 \\
\hline Sent & 11787 & -0.007 & 0.342 & -1.055 & -0.044 & 13.197 \\
\hline Sent 0 & 11787 & -0.006 & 0.346 & -1.055 & -0.044 & 13.197 \\
\hline ALE & 11787 & 0.336 & 0.234 & 0 & 0.31 & 8.009 \\
\hline TCD & 11787 & -0.971 & 2.565 & -6.604 & -0.489 & 6.792 \\
\hline TCD 0 & 11787 & 0.409 & 2.291 & -4.807 & 0.634 & 4.561 \\
\hline CYP & 11787 & 7.191 & 4.663 & 0.296 & 6.436 & 34.036 \\
\hline GDP & 11787 & 0.085 & 0.057 & -0.374 & 0.087 & 0.615 \\
\hline GS & 11787 & 51.068 & 246.852 & -4.796 & 11.531 & 11267.000 \\
\hline Size & 11787 & 9.522 & 0.508 & 7.765 & 9.463 & 12.282 \\
\hline Cash & 11787 & 0.125 & 0.113 & 0 & 0.092 & 0.887 \\
\hline FCF & 11787 & 0.054 & 0.108 & -1.686 & 0.048 & 2.005 \\
\hline CYP & 11787 & 7.185 & 4.657 & 0.296 & 6.436 & 34.036 \\
\hline Virtual variable & 11787 & & Value=1 & & Value=0 & \\
\hline Control & 11787 & 0.5 & Frequency=2625 & & Frequency=9162 \\
\hline State & 0.5 & Frequency=542 & & Frequency=11245 \\
\hline Pollute & 11787 & Frequency=1685 & & Frequency=10102 \\
\hline
\end{tabular}

\section{Benchmark regression analysis}

Table 3 shows the benchmark regression results of formula (1), the models (1) and (2) are the regression results of fixed effect and random effect with the listed companies' R\&D investment as the explained variable, and the models (3) and (4) are the regression results of fixed effect and random effect with the listed companies' R\&D personnel as the explained variable. 
Table 3

Benchmark regression results

\begin{tabular}{|c|c|c|c|c|}
\hline \multirow[t]{2}{*}{ Variable name } & \multicolumn{2}{|l|}{ InCRD } & \multicolumn{2}{|l|}{ InCRP } \\
\hline & Fixed effect(1) & Random effect(2) & Fixed effect(3) & Random effect(4) \\
\hline \multirow[t]{2}{*}{ AQI } & $-0.2097 \star \star \star$ & $-0.1894^{\star * *}$ & $-0.0388^{*}$ & $-0.0498 * \star \star$ \\
\hline & $(-6.9603)$ & $(-8.0856)$ & $(-1.6695)$ & $(-2.5913)$ \\
\hline \multirow[t]{2}{*}{ ALE } & 0.0859 & 0.0299 & -0.0368 & -0.0628 \\
\hline & $(0.9769)$ & $(0.3633)$ & $(-0.8256)$ & $(-1.4555)$ \\
\hline \multirow[t]{2}{*}{ CYP } & 0.0104 & $0.0165^{\star \star \star}$ & 0.0117 & $0.0114^{\star \star \star}$ \\
\hline & $(0.6911)$ & (3.2147) & $(1.1741)$ & $(2.7188)$ \\
\hline \multirow[t]{2}{*}{ GDP } & -0.0320 & 0.0703 & -0.0547 & -0.0008 \\
\hline & $(-0.3022)$ & $(0.6790)$ & $(-0.6736)$ & $(-0.0102)$ \\
\hline \multirow[t]{2}{*}{ Size } & $1.7822^{\star \star \star}$ & $1.6914^{\star \star \star}$ & $1.3783^{\star \star \star}$ & 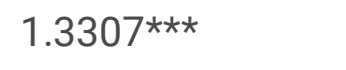 \\
\hline & $(21.6285)$ & $(31.4112)$ & $(21.6825)$ & $(29.1435)$ \\
\hline \multirow[t]{2}{*}{ Cash } & $-0.5255^{\star \star \star}$ & $-0.4267^{\star \star \star}$ & $-0.4269 \star \star \star$ & $-0.3681^{\star \star \star}$ \\
\hline & $(-7.0324)$ & $(-5.9688)$ & $(-5.5348)$ & $(-4.9537)$ \\
\hline \multirow[t]{2}{*}{ FCF } & $0.3788^{* \star *}$ & $0.4195^{\star \star \star}$ & $0.2001^{\star \star \star}$ & $0.2198 * \star \star$ \\
\hline & $(4.4937)$ & (4.9398) & $(2.8784)$ & $(3.1568)$ \\
\hline \multirow[t]{2}{*}{ TCD } & $-0.0085^{\star \star \star}$ & $-0.0114 * \star \star$ & 0.0002 & -0.0011 \\
\hline & $(-3.1615)$ & $(-4.3038)$ & $(0.1531)$ & $(-0.7476)$ \\
\hline \multirow[t]{2}{*}{ Cons } & $-12.2772^{\star \star \star}$ & 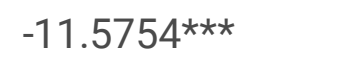 & $-7.5244^{\star \star \star}$ & $-7.0937 * \star \star$ \\
\hline & $(-15.1026)$ & $(-22.6254)$ & $(-12.0061)$ & $(-16.1485)$ \\
\hline Observ & 11,782 & 11,782 & 11,782 & 11,782 \\
\hline R-squared & 0.2565 & & 0.2483 & \\
\hline
\end{tabular}

According to the regression results of model (1)-(4), the estimated coefficients of AQI are all negative at the significant level of $1 \%$, and the economic implications are as follows: Taking model (1) as an example, the regression coefficient of -0.2097 indicates that an increase of 1 unit in the Air Quality Index (AQI) reduces the R\&D investment of listed companies by $20.97 \%$ of the total asset investment at the beginning of the period. It shows that the worse the air quality is, the less the R\&D investment of the listed companies is. 
Table 4

Benchmark regression of intermediary effect of investor sentiment

\begin{tabular}{|c|c|c|c|c|c|c|}
\hline \multirow[t]{2}{*}{ Variable } & (1) & (2) & (3) & (4) & (5) & (6) \\
\hline & InCRD & Sent & InCRD & InCRP & Sent & InCRP \\
\hline \multirow[t]{2}{*}{ Sent } & & & $-0.0662^{\star \star \star}$ & & & $-0.0158 *$ \\
\hline & & & $(-4.8844)$ & & & $(-2.5093)$ \\
\hline \multirow[t]{2}{*}{ AQI } & $-0.2097 * \star \star$ & $0.0684^{\star * \star}$ & $-0.2052^{\star \star \star}$ & $-0.0388^{*}$ & $0.0684^{\star \star \star}$ & $-0.0377^{\star}$ \\
\hline & $(-6.9603)$ & (4.4385) & $(-6.8075)$ & $(-1.6695)$ & (4.4385) & $(-2.6213)$ \\
\hline \multirow[t]{2}{*}{ ALE } & 0.0859 & 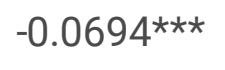 & 0.0813 & -0.0368 & $-0.0694 * \star \star$ & -0.0379 \\
\hline & $(0.9769)$ & $(-3.1939)$ & $(0.9296)$ & $(-0.8256)$ & $(-3.1939)$ & $(-0.8509)$ \\
\hline \multirow[t]{2}{*}{ CYP } & 0.0104 & 0.0022 & 0.0106 & 0.0117 & 0.0022 & 0.0118 \\
\hline & $(0.6911)$ & $(0.4557)$ & $(0.7011)$ & $(1.1741)$ & $(0.4557)$ & (1.1776) \\
\hline \multirow[t]{2}{*}{ GDP } & -0.0320 & -0.0223 & -0.0335 & -0.0547 & -0.0223 & -0.0550 \\
\hline & $(-0.3022)$ & $(-0.3762)$ & $(-0.3167)$ & $(-0.6736)$ & $(-0.3762)$ & $(-0.6782)$ \\
\hline \multirow[t]{2}{*}{ Size } & $1.7822^{\star \star \star}$ & $-0.3062^{\star \star \star}$ & 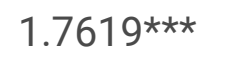 & $1.3783^{\star \star \star}$ & $-0.3062^{\star \star \star}$ & $1.3735^{\star \star \star}$ \\
\hline & (21.6285) & $(-7.8641)$ & $(21.2364)$ & (21.6825) & $(-7.8641)$ & $(21.5553)$ \\
\hline \multirow[t]{2}{*}{ Cash } & $-0.5255^{\star \star \star}$ & $0.4169 * \star \star *$ & $-0.4979 * \star \star$ & $-0.4269 * \star \star$ & $0.4169 * \star \star$ & $-0.4203^{\star * \star}$ \\
\hline & $(-7.0324)$ & (7.4550) & $(-6.6443)$ & $(-5.5348)$ & (7.4550) & $(-5.4334)$ \\
\hline \multirow[t]{2}{*}{ FCF } & $0.3788^{\star \star \star}$ & $0.1226^{\star \star \star}$ & $0.3870 * * \star$ & $0.2001^{* \star *}$ & 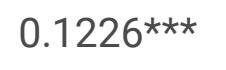 & $0.2020 * \star \star$ \\
\hline & (4.4937) & (3.2590) & $(4.5650)$ & (2.8784) & (3.2590) & $(2.9016)$ \\
\hline \multirow[t]{2}{*}{ TCD } & $0.0085^{\star \star \star}$ & $0.0077^{* \star \star}$ & $0.0080 * \star \star$ & 0.0002 & $0.0077^{\star \star \star}$ & 0.0003 \\
\hline & (3.1615) & $(4.8100)$ & (2.9906) & $(0.1531)$ & (4.8100) & $(0.2380)$ \\
\hline \multirow[t]{2}{*}{ Cons } & $-12.2772^{\star \star \star}$ & $2.6592^{\star \star \star}$ & 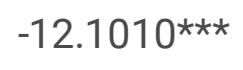 & $-7.5244^{\star \star \star}$ & $2.6592^{\star \star \star}$ & $-7.4824 * \star \star *$ \\
\hline & $(-15.1026)$ & (6.8395) & $(-14.8004)$ & $(-12.0061)$ & (6.8395) & $(-11.9124)$ \\
\hline Observ & 11,782 & 11,782 & 11,782 & 11,782 & 11,782 & 11,782 \\
\hline R-squar & 0.2565 & 0.0395 & 0.2582 & 0.2483 & 0.0395 & 0.2485 \\
\hline
\end{tabular}

Table 4 shows the intermediary effect benchmark regression results of formula (2), and the intermediary variable is investor sentiment (Sent). In Table 4, the models (1)-(3) are the regression results of the intermediary effect with the listed companies' R\&D investment as the explained variable, and the models (4)-(6) are the regression results of the intermediary effect with the listed companies' R\&D personnel as the explained variable. The results show that the explanatory variable air quality (AQI) has a significantly positive influence coefficient $b_{1}$ on the intermediary variable investor sentiment (Sent) whether for $R \& D$ 
investment or for R\&D personnel. It means that air pollution can stimulate investor sentiment. At this time, the explanatory variable air quality (AQI) and the intermediary variable investor sentiment (Sent) in columns 3 and 6 have significant coefficients $c_{1}$ and $c_{2}$ for the explained variable R\&D investment, and $b_{1} c_{2}$ and $c_{1}$ have the same sign, indicating that investor sentiment has a intermediary effect between air quality and R\&D investment. The former regression coefficient for investor sentiment is -0.0662 , and for air quality (AQI) it is -0.2052 , both of which are significant at the $1 \%$ significance level. The latter regression coefficient for investor sentiment is -0.0158 , and for air quality it is -0.0377 , both of which are significant at the $10 \%$ significance level. And the regression coefficient of air quality on investor sentiment is 0.0684 , which is significant at the $1 \%$ significance level. The results of the models (1)-(3) are consistent with those of the models (4)-(6). In general, air quality has a significant inhibitory effect on R\&D Investment, and the inhibitory effect is slightly weakened when the intermediary variables are added. And because air quality has a significant effect on investor sentiment, this approach further restrains the R\&D investment of listed companies. On the whole, with the aggravation of air pollution, the R\&D investment of enterprises will decrease under the capital crowding-out effect and human resource loss effect. Especially, the high-tech talents with stronger ability to avoid pollution and better ability to bear population flow will lead to the decline of innovation quality of enterprises in polluted areas.

From a micro perspective, the higher the degree of air pollution is, the higher the investor sentiment is. And different from the previous research conclusion, it has an indirect inhibitory effect on the R\&D investment of listed companies by using investor sentiment as the influence path. And the indirect effect of this part is -0.0045 . This indicates that the upsurge of investment sentiment caused by the increase of air pollution level has not stimulated the innovation vigor of the listed companies, but may hinder the financing constraints of enterprises and weaken the sensitivity of the R\&D investment of the listed companies, and at the same time, the rationality of managers and the irrationality of investors have a reverse effect, which does not cater to investors and indirectly restrains the R\&D Investment of listed companies. 
Table 5

Benchmark regression of intermediary effect of government supervision

\begin{tabular}{|c|c|c|c|c|c|c|}
\hline \multirow[t]{2}{*}{ Variable } & (1) & (2) & (3) & (4) & (5) & (6) \\
\hline & InCRD & GS & InCRD & InCRP & GS & InCRP \\
\hline \multirow[t]{2}{*}{ GS } & & & $0.0001^{\star \star \star}$ & & & $0.0001 *$ \\
\hline & & & $(3.7468)$ & & & $(1.7671)$ \\
\hline \multirow[t]{2}{*}{ AQI } & $-0.2097 * \star \star$ & 17.4213 *** & -0.2107 *ᄎ* & $-0.0388 *$ & 17.4213 *** & $-0.0399 *$ \\
\hline & $(-6.9603)$ & $(2.8326)$ & $(-7.0893)$ & $(-1.6695)$ & $(2.8326)$ & $(-1.7204)$ \\
\hline \multirow[t]{2}{*}{ ALE } & 0.0859 & 0.5735 & 0.0858 & -0.0368 & 0.5735 & -0.0368 \\
\hline & $(0.9769)$ & $(0.0885)$ & $(0.9779)$ & $(-0.8256)$ & $(0.0885)$ & $(-0.8284)$ \\
\hline \multirow[t]{2}{*}{ CYP } & 0.0104 & $2.4878^{* *}$ & 0.0103 & 0.0117 & $2.4878 * \star$ & 0.0116 \\
\hline & $(0.6911)$ & $(2.3313)$ & $(0.6814)$ & $(1.1741)$ & $(2.3313)$ & $(1.1576)$ \\
\hline \multirow[t]{2}{*}{ GDP } & -0.0320 & -1.9886 & -0.0319 & -0.0547 & -1.9886 & -0.0546 \\
\hline & $(-0.3022)$ & $(-0.0845)$ & $(-0.3014)$ & $(-0.6736)$ & $(-0.0845)$ & $(-0.6723)$ \\
\hline \multirow[t]{2}{*}{ Size } & $1.7822^{\star \star \star}$ & $69.9067 * \star \star *$ & $1.7782^{\star \star \star}$ & $1.3783^{\star \star \star}$ & $69.9067 * \star \star *$ & $1.3739 * * *$ \\
\hline & (21.6285) & $(4.8003)$ & $(21.7415)$ & $(21.6825)$ & $(4.8003)$ & $(21.7172)$ \\
\hline \multirow[t]{2}{*}{ Cash } & $-0.5255^{\star \star \star}$ & -7.9296 & 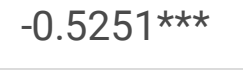 & 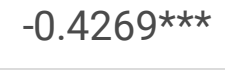 & -7.9296 & 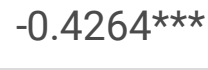 \\
\hline & $(-7.0324)$ & $(-0.5836)$ & $(-7.0309)$ & $(-5.5348)$ & $(-0.5836)$ & $(-5.5321)$ \\
\hline \multirow[t]{2}{*}{ FCF } & $0.3788^{\star \star *}$ & 19.3797 & $0.3777^{* * \star}$ & $0.2001^{\star \star \star \star}$ & 19.3797 & $0.1988^{\star \star \star}$ \\
\hline & $(4.4937)$ & (1.5523) & $(4.4826)$ & $(2.8784)$ & $(1.5523)$ & $(2.8651)$ \\
\hline \multirow[t]{2}{*}{ TCD } & $0.0085^{\star \star \star}$ & 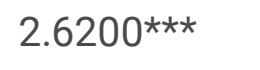 & $0.0087^{\star \star \star \star}$ & 0.0002 & 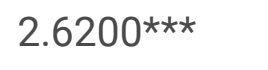 & 0.0001 \\
\hline & (3.1615) & (5.1923) & (3.1998) & $(0.1531)$ & (5.1923) & $(0.0381)$ \\
\hline \multirow[t]{2}{*}{ Cons } & $-12.2772^{\star \star \star *}$ & $-683.3977^{\star \star \star}$ & $-12.2382^{\star \star \star}$ & $-7.5244^{\star \star \star}$ & $-683.3977 * \star \star$ & $-7.4811^{\star \star *}$ \\
\hline & $(-15.1026)$ & $(-4.6944)$ & $(-15.1983)$ & $(-12.0061)$ & $(-4.6944)$ & $(-11.9962)$ \\
\hline Observ & 11,782 & 11,782 & 11,782 & 11,782 & 11,782 & 11,782 \\
\hline R-squar & 0.2565 & 0.0076 & 0.2567 & 0.2483 & 0.0076 & 0.2488 \\
\hline
\end{tabular}

Table 5 shows the intermediary effect benchmark regression results of formula (2), and the intermediary variable is government supervision (GS). In Table 5, the models (1)-(3) are the regression results of the intermediary effect with the listed companies' R\&D investment as the explained variable, and the models (4)-(6) are the regression results of the intermediary effect with the listed companies' R\&D personnel as the explained variable. The results show that the explanatory variable air quality (AQI) has a significantly positive influence coefficient b1 on the intermediary variable government supervision (GS) whether for R\&D 
investment or for R\&D personnel. It means that air pollution will be of effective concern to the government and measures will be taken in response. At this time, the explanatory variable air quality (AQI) and the intermediary variable government supervision (GS) in columns 4 and 6 have significant coefficients $c_{1}$ and $c_{2}$ for the explainatory variable $R \& D$ investment, and $b_{1} c_{2}$ and $c_{1}$ have the same sign, indicating that government supervision has a masking effect between air quality and R\&D investment. The former regression coefficient for government supervision is 0.0001 , and for air quality (AQI) it is -0.2052 , both of which are significant at the $1 \%$ significance level. The latter regression coefficient for government supervision is 0.0001 , and for air quality it is -0.0399 , both of which are significant at the $10 \%$ significance level. And the regression coefficient of air quality on investor sentiment is 17.4213 , which is significant at the $1 \%$ significance level. The results of the models (1)-(3) are consistent with those of the models (4)-(6).

The aggravation of air pollution can indeed attract the effective attention of the government and cause the government to implement the corresponding subsidy policies. The implementation of corresponding subsidy policies can also indirectly increase R\&D investment of listed companies. But at the same time, it may cause enterprise managers to pay too much attention to this kind of speculative profit-seeking and expand the demand for their own interests. Enterprises may be less motivated to innovate, which in turn reduces investment in research and development The crowding-out effect of government supervision may offset or even outweigh its promotional effect.

Since the results of the explained variables in Tables 4 and 5 are consistent, the empirical results of R\&D investment represented by R\&D fund investment and R\&D personnel are robust, and the results of R\&D fund investment are more significant, therefore, the later empirical analysis of this paper only uses R\&D fund investment as the explained variable.

\section{Further discussion-Heterogeneity of listed companies}

\section{Air quality, technical complexity and R\&D investment of listed companies}

Among the results in Tables 4 and 5, it is noteworthy that the urban technical complexity (TCD) is an indicator closely related to enterprise R\&D innovation, and in Tables 4 and 5 , the regression results of technological complexity on enterprise R\&D innovation are both significant at the $1 \%$ level. Technical complexity represents the comparative advantage of urban technology. At present, enterprise innovation is based on the innovation of complex products, not the innovation of single technology, so it needs the support of multi-technology. Therefore, the technological complexity of the cities where the listed companies are located determines the differences in the environments in which they conduct their innovation activities. This paper classifies the technical complexity by means of average value. The cities above the average value are high technical complexity areas, marked as 1 , on the contrary low technical complexity areas, marked as 0 . It is a region with low technical complexity and is recorded as 0 . The empirical results are shown in Tables 6 and 7. 
Table 6

Heterogeneity analysis of technical complexity based on investor sentiment

\begin{tabular}{|c|c|c|c|c|c|c|}
\hline \multirow[t]{3}{*}{ Variable } & (1) & (2) & (3) & (4) & (5) & (6) \\
\hline & \multicolumn{3}{|l|}{$\mathrm{TCD}=1$} & \multicolumn{3}{|l|}{$\mathrm{TCD}=0$} \\
\hline & InCRD & Sent & InCRD & InCRD & Sent & InCRD \\
\hline \multirow[t]{2}{*}{ Sent } & & & 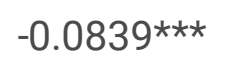 & & & -0.0331 \\
\hline & & & $(-4.2125)$ & & & $(-1.1818)$ \\
\hline \multirow[t]{2}{*}{ AQI } & $-0.1883^{\star \star \star}$ & $0.0744^{\star \star \star}$ & 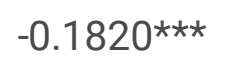 & $-0.2422^{\star \star \star}$ & $0.1137^{\star * *}$ & $-0.2385^{\star \star \star}$ \\
\hline & $(-4.6909)$ & (3.9158) & $(-4.5532)$ & $(-4.9624)$ & $(4.4195)$ & $(-4.8363)$ \\
\hline Control variable & Yes & Yes & Yes & Yes & Yes & Yes \\
\hline \multirow[t]{2}{*}{ Cons } & $-14.7636^{\star \star \star}$ & $2.4895^{\star \star \star}$ & 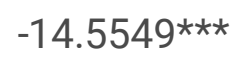 & $-10.6680 * * \star *$ & $2.9073^{\star \star \star}$ & $-10.5717^{\star \star \star \star}$ \\
\hline & $(-13.6394)$ & $(4.8420)$ & $(-13.3668)$ & $(-9.3950)$ & $(4.1917)$ & $(-9.3053)$ \\
\hline Observ & 7,033 & 7,033 & 7,033 & 4,749 & 4,749 & 4,749 \\
\hline R-squar & 0.2688 & 0.0375 & 0.2710 & 0.3305 & 0.0520 & 0.3310 \\
\hline
\end{tabular}

Table 6 presents the grouped regression results of high-tech and low-tech complexity regions, with investor sentiment as the intermediary variable, where the models (1)-(3) are samples of high-tech complexity regions and the models (4)-(6) are samples of low-tech complexity regions. In the models (1)-(3), the influence coefficient $b_{1}$ of explanatory variable air quality (AQI) on investor sentiment (Sent) of intermediary variable was significantly positive. It means that air pollution can stir up investor sentiment. At this point, the explanatory variable air quality (AQI) and the intermediary variable investor sentiment (Sent) in column 3 are both significant for coefficients $c_{1}, c_{2}$ for the explained variable R\&D investment, and $b_{1} c_{2}$ and $c_{1}$ are the same number, indicating that investor sentiment still has an intermediary effect between air quality and $R \& D$ investment. However, in the models (4)-(6), the influence coefficient $b_{1}$ of the explanatory variable air quality (AQI) on the investor sentiment (Sent) of the intermediary variable is significantly positive, but there is no longer an intermediary effect, indicating that investor sentiment, as the impact path of air quality and $R \& D$ investment of listed companies, needs the technical complexity of the region to reach a certain degree, and comparing model (1) and model (4), air quality has stronger inhibition on R\&D Investment of listed companies in low-tech complex areas. As cities become more technologically diverse, on the one hand, enterprises are more likely to have access to complementary technology support, providing a good environment and external support to undertake complex innovation activities. On the other hand, technological diversity can also enhance the possibility of technology integration, which is conducive to the formation of emerging industries, enhance the managers' expectation of future earnings and the competitiveness of the industry, and thus can effectively encourage enterprises to increase R\&D investment. 
Table 7 shows the group regression results for high-tech complexity regions and low-tech complexity regions with government concerns as the intermediary variables, with the same model setting as Table 6 . The coefficients $\mathrm{c}_{1}$ and $\mathrm{c}_{2}$ of the explanatory variable air quality (AQI) and the intermediary variable government concern (GS) in column 3 are significant, and the $b_{1} c_{2}$ and $c_{1}$ are different, indicating that the government is concerned about the masking effect between air quality and R\&D investment. However, in the models (4)-(6), the influence coefficient $b_{1}$ of the explanatory variable air quality (AQI) on investor sentiment (Sent) of the intermediary variable is significantly positive, but $c_{1}$ is not significant, so in low-tech complex areas, government concern cannot be the impact path of air pollution and R\&D investment of listed companies. Comparing model (2) and model (5), the influence coefficient of air quality on government concern in high-tech complexity areas is 1.8849 , and in low-tech complexity areas it is 37.5347 . Both are significant at $1 \%$ level, but the difference is large. The coefficient in Table 5 is 17.4213 , indicating that at present, the government is more sensitive to air pollution and more urgent to promote the improvement of regional innovation ability in the regions with low technological complexity. In this state, the government subsidy does not play a crowding-out role.

Table7 Heterogeneity analysis of technical complexity based on government Concern

\begin{tabular}{|c|c|c|c|c|c|c|}
\hline \multirow[t]{3}{*}{ Variable } & (1) & (2) & (3) & (4) & (5) & (6) \\
\hline & \multicolumn{3}{|l|}{$T C D=1$} & \multicolumn{3}{|l|}{$\mathrm{TCD}=0$} \\
\hline & InCRD & GS & InCRD & InCRD & GS & InCRD \\
\hline \multirow[t]{2}{*}{ GS } & & & $0.0003^{*}$ & & & -0.0000 \\
\hline & & & (1.7118) & & & $(-0.1896)$ \\
\hline \multirow[t]{2}{*}{ AQI } & $-0.1883^{\star \star \star}$ & $1.8849 * \star \star$ & $-0.1888^{\star \star \star}$ & $-0.2422^{\star \star \star}$ & $37.5347^{\star \star \star}$ & $-0.2417^{\star \star *}$ \\
\hline & $(-4.6909)$ & (4.3996) & $(-4.7330)$ & $(-4.9624)$ & $(3.5305)$ & $(-5.0878)$ \\
\hline $\begin{array}{l}\text { Control } \\
\text { variable }\end{array}$ & Yes & Yes & Yes & Yes & Yes & Yes \\
\hline \multirow[t]{2}{*}{ Cons } & 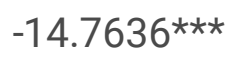 & $-604.9122^{\star \star \star}$ & $-14.5774^{\star \star \star}$ & $-10.6680^{\star \star \star \star}$ & $-671.2972^{\star \star \star}$ & $-10.6777^{\star \star \star *}$ \\
\hline & $(-13.6394)$ & $(-3.2341)$ & $(-13.7161)$ & $(-9.3950)$ & $(-4.5849)$ & $(-9.4735)$ \\
\hline Observ & 7,033 & 7,033 & 7,033 & 4,749 & 4,749 & 4,749 \\
\hline R-squar & 0.2688 & 0.0151 & 0.2706 & 0.3305 & 0.0051 & 0.3305 \\
\hline
\end{tabular}

\section{Air quality, property rights and R\&D investment of listed companies}

According to the nature of the actual controller, this paper defines the property right nature of listed companies (State) as the virtual variable. State takes 1 if it belongs to a state-owned enterprise, and 0 if it belongs to a non-state-owned enterprise. Table 8 is a grouped regression result of the property rights nature with investor sentiment as the intermediary variable, in which the model (1)-(3) is the sample of state- 
owned enterprises, and the model (4)-(6) is the sample of non-state-owned enterprises. The estimation coefficient of AQI on investor sentiment in models (1) - (3) is not significant, while the estimated coefficient of AQI in models (4) - (6) is significantly positive at the level of $1 \%$. The above results show that air pollution has an intermediary effect on R\&D investment of non-state-owned enterprises, while no on the R\&D investment of state-owned enterprises.

Enterprises with different property rights are confronted with different political environments. Non-stateowned enterprises face more stringent regulatory pressure than state-owned enterprises. At the same time, non-state-owned enterprises are likely to bear more environmental responsibility from the government, and investor sentiment in non-state-owned polluting enterprises is notably higher when air pollution levels rise, in this case, the investors will have a "pessimistic expectation" to the expected return and effectiveness, leading to the reduction of their R\&D investment.

Table 8

Heterogeneity analysis of enterprise based on investor sentiment

\begin{tabular}{|c|c|c|c|c|c|c|}
\hline \multirow[t]{3}{*}{ Variable } & (1) & (2) & (3) & (4) & (5) & (6) \\
\hline & \multicolumn{3}{|l|}{ State $=1$} & \multicolumn{3}{|l|}{ State $=0$} \\
\hline & InCRD & Sent & InCRD & InCRD & Sent & InCRD \\
\hline \multirow[t]{2}{*}{ Sent } & & & -0.0803 & & & $-0.0679 * \star *$ \\
\hline & & & $(-0.5662)$ & & & $(-5.0177)$ \\
\hline \multirow[t]{2}{*}{ AQI } & $-0.5334^{\star *}$ & 0.0505 & $-0.5294^{\star \star}$ & -0.2016 *** & $0.0798 * * \star$ & $-0.1962 * \star \star$ \\
\hline & $(-2.1505)$ & $(0.9744)$ & $(-2.0988)$ & $(-6.9542)$ & $(5.1653)$ & $(-6.7861)$ \\
\hline Control variable & Yes & Yes & Yes & Yes & Yes & Yes \\
\hline \multirow[t]{2}{*}{ Cons } & -12.0816 *** & 1.3064 & $-11.9767 * \star \star *$ & $-12.3722^{\star \star \star}$ & $2.7287^{\star \star *}$ & -12.1868 *** \\
\hline & $(-3.5386)$ & $(1.1531)$ & $(-3.5818)$ & $(-14.9896)$ & $(6.8262)$ & $(-14.6594)$ \\
\hline Observ & 542 & 542 & 542 & 11,240 & 11,240 & 11,240 \\
\hline R-squar & 0.1556 & 0.0177 & 0.1563 & 0.2685 & 0.0376 & 0.2704 \\
\hline
\end{tabular}

Table 9 is a grouped regression result with the property right nature as the intermediary variables, in which the model (1)-(3) is the sample of state-owned enterprises, and the model (4)-(6) is the sample of non-stateowned enterprises. In column 3,the coefficient $c_{2}$ of the intermediary variable government concern to the explained variable $R \& D$ investment is not significant, which indicates that there is no intermediary effect in the sample of state-owned enterprises, and the air quality is not significant to the government concern. However, in the models (4)-(6), the coefficient $b_{1}$ of the impact of explanatory variable air quality on the investor sentiment of the intermediary variable is significantly positive, and the $b_{1} c_{2}$ and $c_{1}$ are showing 
opposite signs $\square$ which indicates that there is a masking effect between the government concern on air quality and R\&D investment.

In order to improve the economic performance, local governments will intervene in market competition by means of administrative monopoly to protect the state-owned holding companies. Local governments pay more attention to protecting the interests of state-owned enterprises and give more policy support to stateowned enterprises that are at a disadvantage in the market competition. As a result, government concern is not on its own a path of influence for air pollution and R\&D investment by listed companies, and it is not sensitive to air pollution for state owned enterprises. As air pollution intensifies, state-owned polluters are protected even as the government sets more binding environmental policies, and their R\&D investment is not significantly affected by air pollution. For the non-state-owned enterprises, government concern as a significant intermediary variable, its crowding-out effect on R\&D investment still exists.

Table9 Heterogeneity analysis of enterprises based on the government concern

\begin{tabular}{|c|c|c|c|c|c|c|}
\hline \multirow[t]{3}{*}{ Variable } & (1) & (2) & (3) & (4) & (5) & (6) \\
\hline & \multicolumn{3}{|l|}{ State $=1$} & \multicolumn{3}{|l|}{ State $=0$} \\
\hline & InCRD & GS & InCRD & InCRD & GS & InCRD \\
\hline \multirow[t]{2}{*}{ GS } & & & -0.0000 & & & $0.0001^{* * *}$ \\
\hline & & & $(-0.5510)$ & & & (4.1397) \\
\hline \multirow[t]{2}{*}{ AQI } & $-0.5334^{\star \star}$ & 22.5496 & $-0.5327^{\star \star *}$ & $-0.2016 * \star \star *$ & $21.0234^{\star \star \star}$ & $-0.2039 * * *$ \\
\hline & $(-2.1505)$ & $(0.8900)$ & $(-2.1569)$ & $(-6.9542)$ & $(3.0925)$ & $(-7.0757)$ \\
\hline $\begin{array}{l}\text { Control } \\
\text { variable }\end{array}$ & Yes & Yes & Yes & Yes & Yes & Yes \\
\hline \multirow[t]{2}{*}{ Cons } & -12.0816 *** & -650.4609 & $-12.1015^{\star \star \star}$ & $-12.3722^{\star \star \star}$ & $-670.8661^{\star \star \star}$ & $-12.2982^{\star \star \star}$ \\
\hline & $(-3.5386)$ & $(-1.0173)$ & $(-3.5668)$ & $(-14.9896)$ & $(-4.5015)$ & $(-15.0412)$ \\
\hline Observ & 542 & 542 & 542 & 11,240 & 11,240 & 11,240 \\
\hline R-squar & 0.1556 & 0.0016 & 0.1559 & 0.2685 & 0.0095 & 0.2689 \\
\hline
\end{tabular}

\section{Air quality, polluting enterprises and R\&D investment of listed companies}

The intermediary effect of "air quality-enterprise R\&D investment" may be affected by the characteristics of the pollution degree of the enterprise itself. This article takes the "Notice on the Implementation of Special Emission Limits for Air Pollutants" issued by the Ministry of Environmental Protection as the standard. If the listed company is in the six major industries under the "Notice", it will be defined as a heavy pollution enterprise, and the rest will be defined as light pollution enterprises. In this article, the pollution degree of an enterprise (Pollute) is defined as a virtual variable. If it is a heavily polluting enterprise, the Pollute value is 1 ; if it is a lightly polluting enterprise, the Pollute value is 0 . 
Table 10 presents the grouped regression results of heavy and light polluting enterprises with investor sentiment as the intermediary variable, in which the models (1)-(3) are the samples of heavy polluting enterprises, and (4)-(6) are the samples of light polluting enterprises. Both of them have a significant intermediary effect, and there is no significant difference between the two groups in the regression results of the intermediary variable of investor sentiment. However, in terms of the overall effect, compared with light polluters, heavy polluters' R\&D investment is more restrained by air quality. The above results show that air pollution has a more obvious impact on R\&D investment of heavily polluting enterprises. Heavy polluting enterprises generally belong to high energy-consuming industries, and most of them are local pillar industries. They should bear more responsibility for environmental protection, but they are prone to the phenomenon of 'collusion between government and enterprises', which makes such enterprises pay less attention to environmental protection and do not implement the principle of 'polluter pays'.

Table 11 presents the grouped regression results of heavy and light polluting enterprises with government concern as the intermediary variable, in which the models (1)-(3) are the samples of heavy pollutng enterprises, and (4)-(6) are the samples of light polluting enterprises. There is significant intermediary effect in the sample of heavy polluting enterprises, while there is no intermediary effect in the sample of light polluting enterprises. Comparing model (2) and (5), heavy polluting enterprises are more sensitive to air quality changes than light pollution enterprises.

Table10 Heterogeneity analysis of polluting enterprises based on investor sentiment

\begin{tabular}{|c|c|c|c|c|c|c|}
\hline \multirow[t]{3}{*}{ Variable } & (1) & (2) & (3) & (4) & (5) & (6) \\
\hline & \multicolumn{3}{|l|}{ Pollute=1 } & \multicolumn{3}{|l|}{ Pollute=0 } \\
\hline & InCRD & Sent & InCRD & InCRD & Sent & InCRD \\
\hline \multirow[t]{2}{*}{ Sent } & & & $-0.0878 * \star$ & & & $-0.0648 * \star \star *$ \\
\hline & & & $(-2.4307)$ & & & $(-4.4319)$ \\
\hline \multirow[t]{2}{*}{ AQI } & $-0.3266 * \star$ & $0.0733^{* *}$ & $-0.3202^{\star \star}$ & $-0.2173^{\star \star \star}$ & $0.0790 * * *$ & $-0.2122^{\star \star \star}$ \\
\hline & $(-2.4675)$ & $(2.2616)$ & $(-2.3934)$ & $(-6.8103)$ & $(4.8337)$ & $(-6.6509)$ \\
\hline Control variable & Yes & Yes & Yes & Yes & Yes & Yes \\
\hline \multirow[t]{2}{*}{ Cons } & $-16.3416^{\star \star \star}$ & $2.9118 * \star \star$ & -16.0860 *** & $-11.8502^{\star \star \star}$ & $2.6578 * * \star$ & $-11.6779 \star \star \star *$ \\
\hline & $(-9.6838)$ & $(3.6270)$ & $(-9.4181)$ & $(-13.5173)$ & $(6.2422)$ & $(-13.2420)$ \\
\hline Observ & 1,685 & 1,685 & 1,685 & 10,097 & 10,097 & 10,097 \\
\hline R-squar & 0.2356 & 0.0248 & 0.2376 & 0.2639 & 0.0393 & 0.2657 \\
\hline
\end{tabular}

Table11 Heterogeneity analysis of polluting enterprises based on government concern 


\begin{tabular}{|c|c|c|c|c|c|c|}
\hline \multirow[t]{3}{*}{ Variable } & (1) & (2) & (3) & (4) & (5) & (6) \\
\hline & \multicolumn{3}{|l|}{ Pollute=1 } & \multicolumn{3}{|l|}{ Pollute $=0$} \\
\hline & InCRD & GS & InCRD & InCRD & GS & InCRD \\
\hline \multirow[t]{2}{*}{ GS } & & & $-0.0002^{\star \star}$ & & & 0.0001 \\
\hline & & & $(-3.0115)$ & & & $(0.9857)$ \\
\hline \multirow[t]{2}{*}{ AQI } & $-0.2266^{\star \star}$ & $82.9613^{\star \star}$ & $-0.2061^{\star \star}$ & $-0.2173^{\star \star *}$ & $12.2183^{\star \star}$ & 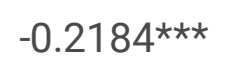 \\
\hline & $(-2.4675)$ & $(2.1959)$ & $(-2.2836)$ & $(-6.8103)$ & $(2.4292)$ & $(-6.9294)$ \\
\hline $\begin{array}{l}\text { Control } \\
\text { variable }\end{array}$ & Yes & Yes & Yes & Yes & Yes & Yes \\
\hline \multirow[t]{2}{*}{ Cons } & $-16.3416^{* \star \star}$ & $-1,158.3991^{\star \star \star}$ & $-16.6283^{\star \star \star}$ & $-11.8502^{\star \star \star}$ & $-608.0354^{\star \star \star}$ & $-11.7974^{\star \star \star}$ \\
\hline & $(-9.6838)$ & $(-3.4651)$ & $(-9.7179)$ & $(-13.5173)$ & $(-3.8357)$ & $(-13.6379)$ \\
\hline Observ & 1,685 & 1,685 & 1,685 & 10,097 & 10,097 & 10,097 \\
\hline R-squar & 0.2356 & 0.0303 & 0.2379 & 0.2639 & 0.0045 & 0.2644 \\
\hline
\end{tabular}

\section{Air quality, key regulatory enterprises and R\&D investment of listed companies}

According to the degree of supervision of listed companies, whether listed companies are key regulatory enterprises (Control) is defined as a virtual variable. For key regulatory enterprises, the Control value is 1 ; for non-key regulatory enterprises, the Control value is 0 . Table 12 is the grouped regression result of supervising enterprises with investor sentiment as the intermediary variable, where the models (1)-(3) are the samples of key regulatory enterprises and (4)-(6) are the samples of non-key regulatory enterprises. Both of them have significant intermediary effect, and the intermediary effect of non-key regulatory enterprises is more significant than that of key regulatory enterprises. Table 13 shows the grouped regression results with government concern as the intermediary variable, and the model is set the same as the above. For key regulatory enterprises, government concern does not have a significant intermediary effect, but for non-key enterprises, government concern has a significant intermediary effect, which indicates that key regulatory measures for enterprises can offset the crowding-out effect of government subsidies.

Table12 Heterogeneity analysis of key regulatory enterprises based on investor sentiment 


\begin{tabular}{|c|c|c|c|c|c|c|}
\hline \multirow[t]{3}{*}{ Variable } & (1) & (2) & (3) & (4) & (5) & (6) \\
\hline & \multicolumn{3}{|l|}{ Control=1 } & \multicolumn{3}{|l|}{ Control $=0$} \\
\hline & InCRD & Sent & InCRD & InCRD & Sent & InCRD \\
\hline \multirow[t]{2}{*}{ Sent } & & & $-0.0746 *$ & & & $-0.0683^{\star * \star}$ \\
\hline & & & $(-1.8050)$ & & & $(-4.5754)$ \\
\hline \multirow[t]{2}{*}{ AQI } & $-0.3243^{\star \star \star}$ & $0.1271^{\star \star \star}$ & 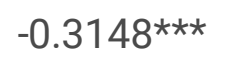 & $-0.2010 * \star \star *$ & $0.0714 * \star \star$ & $-0.1961^{\star \star \star}$ \\
\hline & $(-3.8187)$ & (3.7589) & $(-3.7136)$ & $(-5.6511)$ & (3.7004) & $(-5.5138)$ \\
\hline Control variable & Yes & Yes & Yes & Yes & Yes & Yes \\
\hline \multirow[t]{2}{*}{ Cons } & 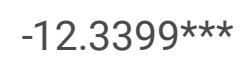 & 0.1777 & $-12.3266^{\star \star \star}$ & 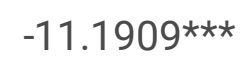 & $3.3082^{\star * *}$ & $-10.9651^{\star \star \star}$ \\
\hline & $(-6.6044)$ & $(0.2459)$ & $(-6.5994)$ & $(-11.7241)$ & $(6.8788)$ & $(-11.3830)$ \\
\hline Observ & 2,624 & 2,624 & 2,624 & 9,158 & 9,158 & 9,158 \\
\hline R-squar & 0.1610 & 0.0144 & 0.1625 & 0.2479 & 0.0451 & 0.2501 \\
\hline
\end{tabular}

Table13 Heterogeneity analysis of key regulatory enterprises based on government concern

\begin{tabular}{|c|c|c|c|c|c|c|}
\hline \multirow[t]{3}{*}{ Variable } & (1) & (2) & (3) & (4) & (5) & (6) \\
\hline & \multicolumn{3}{|l|}{ Control=1 } & \multicolumn{3}{|l|}{ Control $=0$} \\
\hline & InCRD & GS & InCRD & InCRD & GS & InCRD \\
\hline \multirow[t]{2}{*}{ GS } & & & 0.0001 & & & $-0.0001^{* *}$ \\
\hline & & & $(0.9572)$ & & & $(-2.5112)$ \\
\hline \multirow[t]{2}{*}{ AQI } & $-0.3243^{* \star *}$ & 15.9739 & $-0.3258 * \star \star$ & $-0.2010 * \star \star$ & $27.0198 * \star$ & $-0.1992 * \star \star$ \\
\hline & $(-3.8187)$ & $(0.7800)$ & $(-3.8461)$ & $(-5.6511)$ & (2.3638) & $(-5.8071)$ \\
\hline $\begin{array}{l}\text { Control } \\
\text { variable }\end{array}$ & Yes & Yes & Yes & Yes & Yes & Yes \\
\hline \multirow[t]{2}{*}{ Cons } & $-12.3399 * \star \star$ & -441.3144 & $-12.2989 * \star \star \star$ & 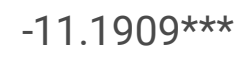 & $-676.0079 * \star \star$ & 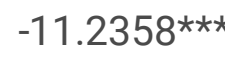 \\
\hline & $(-6.6044)$ & $(-1.6432)$ & $(-6.5722)$ & $(-11.7241)$ & $(-3.9024)$ & $(-11.8263)$ \\
\hline Observ & 2,624 & 2,624 & 2,624 & 9,158 & 9,158 & 9,158 \\
\hline R-squar & 0.1610 & 0.0071 & 0.1614 & 0.2479 & 0.0063 & 0.2482 \\
\hline
\end{tabular}




\section{Endogenous testing}

Because there are many factors that affect enterprise R\&D Investment, this paper may have the problem of missing variables. In addition, there may be a two-way causality between enterprise R\&D investment and air quality, and enterprise R\&D investment can improve air quality after achieving the expected benefits.

Referring to the related research, this paper selects the two variables of rainfall and relative humidity as the instrumental variables of air pollution (Xie and Lin, 2020). The results of the instrumental variable method show that the relevant conclusions of this paper are still valid (As shown in Table 14).

Table 14

Regression results of the instrumental variable method

\begin{tabular}{|lll|}
\hline Variable name & InCRD & InCRP \\
\hline AQI & $-0.2137^{\star \star \star *}$ & $-0.0433^{\star}$ \\
\hline Cons & $(-7.3404)$ & $(-1.8654)$ \\
\hline Control variable & $-12.5545^{\star \star \star}$ & $-6.3412^{\star \star \star}$ \\
\hline Observ & $(-16.2045)$ & $(-13.5546)$ \\
\hline Yes & Yes \\
\hline Exogeneity test & 11,782 & 11,782 \\
\hline
\end{tabular}

\section{Variable substitution test}

In order to ensure the robustness of the results of this paper, in addition to the explained variables represented by R\&D investment and R\&D personnel investment, this paper also replaces the technical complexity of the control variable (large class) with the technical complexity of the small class $\left(\mathrm{TCD}_{0}\right)$. At the same time, the investor sentiment (Sent) is replaced by the cumulative monthly return Sent ${ }_{0}$, which is 6 months behind the first period and does not consider the cash dividend. As shown in Table 15, the conclusions of this paper are still valid. 
Table 15

Regression results of the variable substitution method

\begin{tabular}{|c|c|c|c|c|c|c|}
\hline \multirow[t]{2}{*}{ Variable } & (1) & (2) & (3) & (4) & (5) & (6) \\
\hline & InCRD & Sent $_{0}$ & InCRD & InCRD & GS & InCRD \\
\hline \multirow[t]{2}{*}{ Sent $_{0}$} & & & $-0.0639 * \star \star$ & & & \\
\hline & & & $(-4.7554)$ & & & \\
\hline \multirow[t]{2}{*}{ AQI } & $-0.2208 * \star \star$ & $0.0977^{\star \star \star}$ & $-0.2052^{\star \star \star}$ & $-0.2208^{\star * \star}$ & $23.6507 * \star \star$ & $-0.2219 * \star \star$ \\
\hline & $(-7.2137)$ & (6.5333) & $(-6.8086)$ & $(-7.2137)$ & (3.5218) & $(-7.3686)$ \\
\hline \multirow[t]{2}{*}{ GS } & & & & & & $0.0001^{* \star *}$ \\
\hline & & & & & & $(4.4442)$ \\
\hline \multirow[t]{2}{*}{ Constant } & $-12.3011^{\star \star \star}$ & $2.9687^{\star \star \star}$ & $-12.1011^{\star \star \star *}$ & $-12.3011^{\star \star \star}$ & 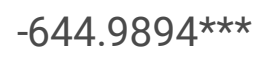 & $-12.2698^{\star \star \star}$ \\
\hline & $(-15.1678)$ & (7.5399) & $(-14.7955)$ & $(-15.1678)$ & $(-4.4346)$ & $(-15.2665)$ \\
\hline Observ & 11,782 & 11,782 & 11,782 & 11,782 & 11,782 & 11,782 \\
\hline R-squared & 0.2551 & 0.0639 & 0.2581 & 0.2551 & 0.0100 & 0.2552 \\
\hline
\end{tabular}

\section{Conclusions And Policy Recommendations}

Based on the data of Shanghai and Shenzhen A-share listed companies from 2015 to 2019, this paper studies the impact path of air quality on R\&D investment of listed companies from the perspectives of investor sentiment and government concern. The findings are as follows:

QIn general, air quality has a significant inhibitory effect on R\&D investment. Air quality has a significant role in promoting investor sentiment, which further inhibits the investment in R\&D of listed companies.

$\bigotimes$ Air pollution will cause effective government concern, and there is a masking effect between air quality and R\&D investment.

Furthermore, this paper draws the following conclusions from the perspectives of regional technical complexity, property rights, whether it is a polluting enterprise, whether it is a key regulatory enterprise.

$\nabla$ As the impact path of air quality and R\&D investment of listed companies, investor sentiment needs the technical complexity of the region to cross a certain threshold before it can play a role, moreover, air quality has a stronger inhibition on R\&D investment of listed companies in low-tech complex areas; the government's sensitivity to air pollution is higher in low-tech complexity areas where government concern cannot be an impact path for air pollution and R\&D investment of listed companies.

$\triangle$ Air pollution has an intermediary effect on R\&D investment of non-state-owned enterprises, but no on R\&D investment of state-owned enterprises; in the sample of state-owned enterprises, government concern has 
no intermediary effect, and air quality has no significant effect on government concern. But in non-stateowned enterprise samples, government concern has a masking effect between air quality and R\&D investment.

Q In terms of total effect, heavy polluting enterprises have a stronger inhibitory effect on enterprise R\&D investment than light polluting enterprises, and air pollution has a more obvious effect on R\&D investment of heavy polluting enterprises; with government concern as an intermediary variable, the sample of heavy polluting enterprises has a significant intermediary effect, but in the sample of light polluting enterprises, there is no intermediary effect. Heavy polluters are more sensitive to changes in air quality than light polluters.

With investor sentiment as the intermediary variable, there is significant intermediary effect for both key regulatory enterprises and non-key regulatory enterprises, and the intermediary effect for the non-key regulated enterprises is more significant. For key regulatory enterprises, government concern does not have a significant intermediary effect, while for non-key enterprises, government concern has a significant intermediary effect, which indicates that key regulatory measures for enterprises can offset the crowdingout effect caused by government subsidies.

Based on the conclusions, this paper makes the following policy recommendations:

$\nabla$ The R\&D investment of listed companies has a negative response to air quality, and for the government, it is necessary to implement different environmental protection policies for different enterprises, strengthen the management of state-owned enterprises and heavy polluting enterprises, and rectify them actively. For other enterprises, the government should stimulate the "shock potential", so that "polluter pays" concept will "deep into the enterprises". We should rapidly improve the supply capacity of scientific and technological innovation, and attach great importance to the system capacity and leading talents. For enterprises, it is necessary to speed up the formation of a good environment for personnel training and use, to coordinate the internal relations of organizations, and to accelerate the innovation of perfect management mode.

Q Government concern, that is, the government's subsidy to enterprises, has a masking effect between air quality and R\&D investment. On the one hand, the government should strengthen the mechanism of supervision and inspection, link the amount of subsidies received by enterprises to their performance, restrict the use of subsidies, and enhance the innovation vitality and enthusiasm of enterprises. On the other hand, enterprises should seize the opportunity of information technology revolution, take market demand as the fundamental driving force of scientific and technological innovation, attract global innovation resources, and expand development space.

Q Local governments should accelerate the formation of industrial technology and knowledge system, ensure the security of regional industrial chain and supply chain, and optimize the allocation of innovation factors, in order to enhance the innovation vitality and innovation ability of enterprises and promote their convergence to enterprises.

\section{Declarations}


Ethics approval and consent to participateINot applicable

Consent for publication $\amalg$ Not applicable

Availability of data and materials $\square$ The datasets used and analyzed during the current study are available from the corresponding author on reasonable request.

Competing interestsロThe authors declare that they have no competing interests.

Funding: This work was supported by the National Social Science Fund of China (21BTJ050) and Jiangsu college Philosophy and social science research project (2021SJA2405)

\section{Authors' contributions:}

Jialiang Yang: Analyzed and interpreted the Green Bond data regarding the financing cost. And analyzed and interpreted the data of Pro-Environmental Factors.

Dan He: A major contributor in writing the manuscript and collecting the data. And Reviewing and editing the manuscript. All authors read and approved the final manuscript.

Acknowledgments: We thank all the editors for permitting the use of the vineyards where this research was done.

\section{References}

1. Brown GW, Cliff MT (2005) Investor sentiment and asset valuation. J Bus 78(2):78 (2):405-440. https://doi.org/10.1086/427633

2. Baker M, Wurgler J (2004) A catering theory of dividends. The J Finance 59(3):1125-1165. https://doi.org/10.1111/j.1540-6261.2004.00658.x

3. Buisseret TJ, Cameron H, Georghiou L (1995) What difference does it make? Additionality in the public support of R\&D in large firms. Int J Technol Manag 10(4):587-600. https://www.inderscienceonline.com/doi/abs/10.1504/IJTM.1995.025644

4. Baron RM, Kenny DA (1986) The Moderator-mediator Variable Distinction in Social Psychological Research: Conceptual, Strategic, and Statistical Considerations. J Pers Soc Psychol 51(6):1173-1182. https://pubmed.ncbi.nlm.nih.gov/3806354/

5. Cui LB, Duan HB, Mo JL, Song ML (2021) Ecological compensation in air pollution governance: China's efforts, challenges, and potential solutions. Int Rev Econ Finance 74:pp1-11. https://doi.org/10.1016/j.irfa.2021.101701

6. Du GD, Shin KJ, Managi S (2018) Variability in impact of air pollution on subjective well-being. Atmos Environ 183:175-208. https://doi.org/10.1016/j.atmosenv.2018.04.018

7. Dolan P, Laffan K (2016) Bad air days: The effects of air quality on different measures of subjective well-being. J Benefit-Cost Anal 7: 147-195. https://xueshu.baidu.com/usercenter/paper/show? paperid $=9 \mathrm{e} 64 \mathrm{~b} 89 \mathrm{ec} 4 \mathrm{e} 7898028 \mathrm{a} 1022 \mathrm{df} 91 \mathrm{e} 4 \mathrm{af} 4$ 
8. Ding XY, Guo MM, Yang T (2021) Air pollution, local bias, and stock returns. Finance Res Lett 39:pp16. https://doi.org/10.1016/j.frl.2020.101576

9. Dang TV, Xu ZX (2018) Market Sentiment and Innovation Activities. J Financ Quant Anal 53(3):11351161. https://doi.org/10.1017/S0022109018000078

10. De Pretto L, Acreman S, Ashfold MJ, Mohankumar SK, Campos-Arceiz A (2015) The link between knowledge, attitudes and practices in relation to atmospheric haze pollution in Peninsular Malaysia. PLoS One 10(12):1-18. http://doi.org/10.3886/E42859V1

11. Gao WH, Zhang JQ (2020) How does the weather affect individual behavior and business activitiesLiterature review on the influence mechanism of weather elements. Econ manag 42(1):194-208. https://kns.cnki.net/kns8/defaultresult/index .(in Chinese)

12. Han X, Liu YQ, Gao H, Ma JM, Mao XX, Wang YT, Ma XD (2017) Forecasting PM2.5 induced male lung cancer morbidity in China using satellite retrieved PM2.5 and spatial analysis. Sci Total Environ 607608:1009-1017. https://doi.org/10.1016/j.scitotenv.2018.04.382

13. He D, Yang JL, Wang ZM, Li WC (2020) Has the manufacturing policy helped to promote the logistics industry? Plos One 15(7):pp1-21. https://doi.org/10.1371/journal.pone.0235292

14. Hirshleifer D, Shumway T (2003) Good day sunshine: Stock returns and the weather. J Finance 58(3):1009-1032. https://doi.org/10.1111/1540-6261.00556

15. Hein W, Wilson C, Lee B, Rajapaksa D, de Moel H, Athukorala W, Managi S (2019) Climate change and natural disasters: Government mitigation activities an public property demand response. Land use policy 82:436-443. https://doi.org/10.1016/j.landusepol.2018.12.026

16. Hansen GS, Hill CWL (1991) Are institutional investors myopic? A time-series study of four technologydriven industries. Strategic Manage J 12(1):1-16.

https://onlinelibrary.wiley.com/doi/abs/10.1002/smj.4250120102

17. Jacobsen B, Marquering W (2008) Is it the weather? J Bank Financ 32(4):526-540. https://doi.org/10.1016/j.jbankfin.2007.08.004

18. Jia LL, Nam E, Chun D (2021) Impact of Chinese Government Subsidies on Enterprise Innovation: Based on a Three-Dimensional Perspective. Sustainability 13(3):pp1-22. https://doi.org/10.3390/su13031288

19. Liu GX, Dong XC, Kong ZY, Dong KY (2021) Does national air quality monitoring reduce local air pollution? The case of PM2.5 for China. J Environ Manage 296:1-11.

https://doi.org/10.1016/j.jenvman.2021.113232

20. Li X, Wang YT, Zhou HC, Shi L (2020) Has China's war on pollution reduced employment? Quasiexperimental evidence from the Clean Air Action. J Environ Manage 260:1-10. https://doi.org/10.1016/j.jenvman.2019.109851

21. Liu XX, Dong XY, Li S, Ding YT, Zhang M (2021) Air pollution and high human capital population migration: An empirical study based on 35 major cities in China. Sustain Prod Consump 27:643-652. https://doi.org/10.1016/j.spc.2021.01.032 
22. Lim YH, Kim H, Kim JH, Bae S, Park HY, Hong YC (2012) Air pollution and symptoms of depression in elderly adults. Environ Health Perspect 120(7):1023-1028. https://doi.org/10.1289/ehp.1104100

23. Lu YL, Wang Y, Zuo J, Jiang HQ, Huang DC (2018) Characteristics of public concern on haze in China and its relationship with air quality in urban areas. Sci Total Environ 637-638:1597-1606. https://doi.org/10.1016/j.scitotenv.2018.04.382

24. Nofsinger JR (2005) Social mood and financial economics. J Behav Financ 6(3):144-160. https://doi.org/10.1207/s15427579jpfm06034

25. Power MC, Kioumourtzoglou MA, Hart JE, Okereke Ol, Laden F, Weisskopf MG (2015) The relation between past exposure to fine particulate air pollution and prevalent anxiety: Observational cohort study. BMJ 350:h1111. https://doi.org/10.1136/bmj.h1111

26. Polk C, Sapienza P (2009) The stock market and corporate investment: a test of catering theory. Rev Financ Stud 22(1):187-217. https://doi.org/10.1093/rfs/hhn030

27. Sanduijav C, Ferreira S, Filipski M, Hashida Y (2021) Air pollution and happiness: Evidence from the coldest capital in the world. Ecol Econ 187:1-20. https://doi.org/10.1016/j.ecolecon.2021.107085

28. Song Y, Zhang KK, Hong XP, Li XY (2021) A novel multi-objective mutation flower pollination algorithm for the optimization of industrial enterprise R\&D investment allocation. Appl Soft Comput 109:pp1-14. https://doi.org/10.1016/j.asoc.2021.107530

29. Tang SY, Yan QL, Shi W, Wang X, Sun XD, Yu PB, Wu JH, Xiao YN (2018) Measuring the impact of air pollution on respiratory infection risk in China. Environ Pollut 232:477-486.

https://doi.org/10.1016/j.envpol.2017.09.071

30. Vega GC, Gross A, Birkved M (2021) The impacts of plastic products on air pollution-A simulation study for advanced life cycle inventories of plastics covering secondary microplastic production. Sustain Prod Consump 28:848-865. https://doi.org/10.1016/j.spc.2021.07.008

31. Wang ZX, Qi ZY, Zhu L (2021) Latitudinal and longitudinal variations in the impact of air pollution on well-being in China. Environ Impact Assess Rev 90:1-10. https://doi.org/10.1016/j.eiar.2021.106625

32. Wu QN, Lu J (2020) Air pollution, individual investors, and stock pricing in China. Int Rev Econ Finance 67:267-287. https://doi.org/10.1016/j.iref.2020.02.001

33. Wu QQ, Hao Y, Lu J (2018) Air pollution, stock returns, and trading activities in China. Pac-Basin Financ J 51:342-365. https://doi.org/10.1016/j.pacfin.2018.08.018

34. Wang T, Peng JC, Wu L (2021) Heterogeneous effects of environmental regulation on air pollution: evidence from China's prefecture-level cities. Environ Sci Pollut Res 28:pages25782-25797. https://doi.org/10.1007/s11356-021-12434-7

35. Wang YY, Lu T, Qiao YB (2021) The effect of air pollution on corporate social responsibility performance in high energy-consumption industry: Evidence from Chinese listed companies. J Clean Prod 280:pp1-12. https://doi.org/10.1016/j.jclepro.2020.124345

36. Xiang D, Zhao TZ, Zhang N (2021) Does public subsidy promote sustainable innovation? The case of Chinese high-tech SMEs. Environ Sci Pollut Res. https://doi.org/10.1007/s11356-021-14555-5 
37. Xie J, Lin XC (2020) Study on the impact of air pollution on the investment behavior of polluting enterprises-from the perspective of "pessimistic expectation". Econ Rev 05:124-136. https://kns.cnki.net/kns8/defaultresult/index

38. Zhang N, Zhao KK, Yu YT (2020) The effect of environmental regulation on air pollution, productivity, and factor structure: a quasi-natural experiment evidence from China. Environ Sci Pollut Res 27:20392-20409. https://doi.org/10.1007/s11356-020-08462-4

39. Zúñiga-Vicente JA, Alonso-Borrego C, Forcadell FJ, Galán JI (2014) Assessing the effect of public subsidies on firm R\&D investment: a survey. J Econ Surv 28(1):36-67. https://doi.org/10.1111/j.14676419.2012.00738.x

\section{Figures}

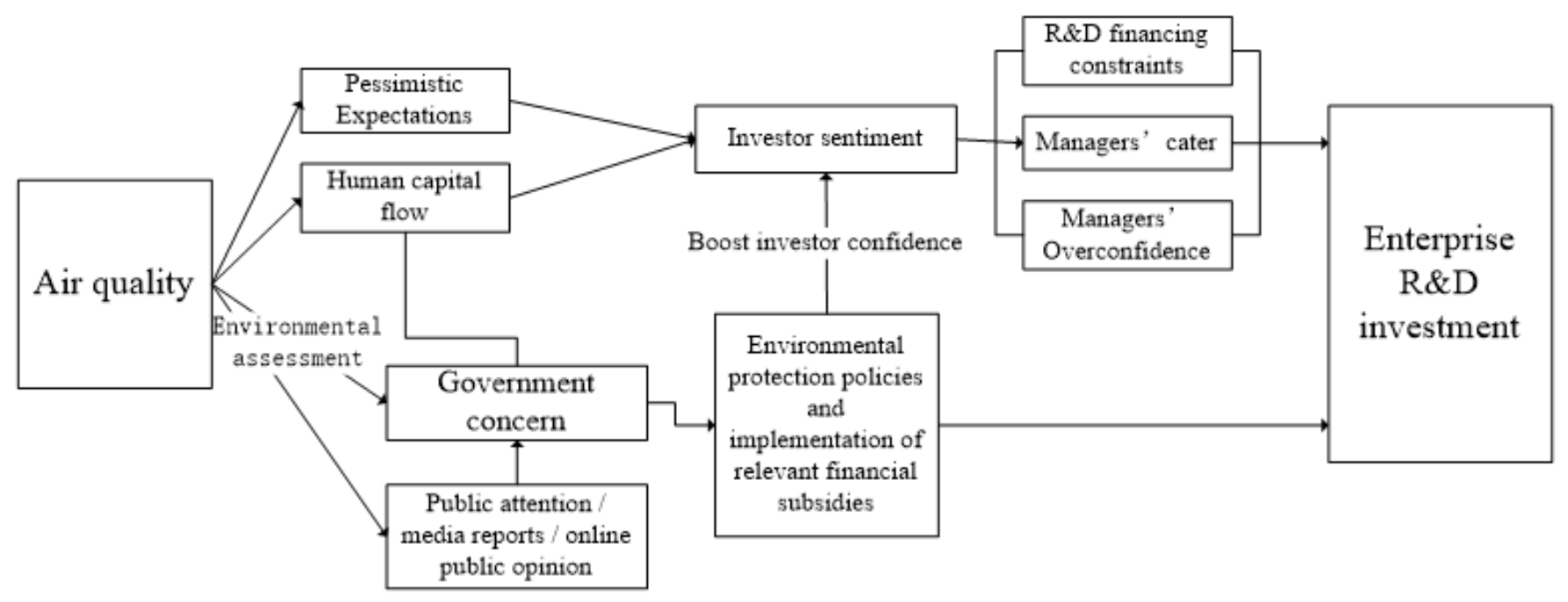

Figure 1

The mechanism of air pollution affecting enterprise R\&D investment behavior 